\title{
THE FUTURE OF W. WARREN WAGAR
}

Stephen K. Sanderson

Department of Sociology

Indiana University of Pennsylvania

Indiana, PA 15705-1087 USA

sksander@grove.iup.edu

Copyright 1996 by stephen K. Sanderson.

v. $6 / 10 / 96$

In his fascinating book A Short History of the Future, published in 1992, w. Warren wagar lays out a futuristic vision of the world over the next two hundred years that draws extensively on Immanuel Wallerstein's world-system theory. In the year 2001 began the last of the great Kondratieff upswings of the capitalist world-economy. That economy had come to be increasingly dominated by a few giant corporations, so that by 201512 "megacorps" had assumed control of the world-economy and the governments of the major capitalist powers. The Kondratieff upswing ran its course by the early 2030 s and then a devastating worldwide depression set in, the lowest point of which was reached in 2043 .

The world of the early twenty-first century was rife with massive social problems, some of the most serious of which were environmental in nature. The most catastrophic event of the twenty-first century, however,

\section{[Page 1]}

\section{Joumal of World-Systems Research}

was the nuclear holocaust of 2044. This holocaust destroyed most of North America, Europe, and the I ndian subcontinent, and within a year of the catastrophe some 70 percent of the earth's population had died, either from the direct effects of the holocaust or from the nuclear winter that followed. Most of the survivors were in the Southern hemisphere. Prior to the holocaust a political party known as the world Party had formed. After the nuclear holocaust, this party began working for the creation of a world socialist commonwealth, and this became a reality in 2062. The economy was converted into a form of socialism that was devoted to the production of use-values rather than exchange-values. The work specialization and work hierarchies characteristic of capitalism were abolished, and workers were required to learn a variety of skills and to rotate jobs over time. ultimately the class hierarchy came to be eliminated, and everyone had a guaranteed minimum income as long as they worked; those who chose not to work received a half-share. Medical care was free to everyone, as were 
such things as schooling and public transport.

On the political side the Commonwealth abolished all national boundaries and state sovereignties. The Commonwealth was a single world state that was organized into 1,000 departments. There was a People's Congress, whose members were elected to office, and every department was allowed two representatives. The Commonwealth established a system of world courts and a world militia with a monopoly of armed force. Wagar describes the Commonwealth as relatively democratic in structure, and opposition parties to the world Party

\section{[Page 2]}

\section{Journal of World-Systems Research}

\section{were allowed.}

It is clear, though, that the commonwealth did not allow many of the liberties that prevail today in the capitalist democracies. No one was allowed to form groups that could secede from the Commonwealth, no free economic enterprise was permitted, and religious and other minorites had no right of self-determination. Individuals and groups thought to be a threat to the Commonwealth were put under surveillance, and there were various restrictions on the right of free speech. The Commonwealth was also characterized by a horrendous bureaucratism.

Dissent against the Commonwealth grew over time and new political parties formed. The most important of these was the Small Party, which wanted to abolish the Commonwealth and establish a highly decentralized political system that permitted the existence of many small and highly autonomous political communities. The Smalls received increasing pop ular support over time, and by 2147 they had won 67 percent of the seats in the People's Congress. Once this party became the dominant party, the Commonwealth was disassembled. In its place grew up 41,525 autonomous communities, which were allowed to choose their own forms of government, economy, and religion. They were entitled to revive capitalism if they wished, and many in fact did so. It turned out that the smalls had no interest in power or self-perpetuation, and they were willing to give up the reins of power quite happily. The party thus disbanded in 2159, and the world it left behind was strikingly different from the world of the Commonwealth. How realistic is this scenario of the future? We

\section{[Page 3]}

\section{Journal of World-Systems Research}


contradictions, and that it only has so much life left in it. It has turned out to be a much more flexible, vigorous, and adaptive system than Marx and early Marxists ever thought, and thus it has survived much longer than predicted. Nevertheless, it will eventually run up against its limitations, and this is likely to occur within the next century or so, perhaps even less. So any prediction of the demise of capitalism is quite sensible. Will capitalism be rep laced by some sort of socialism? This is perhaps as likely an outcome as any other, and it is certainly more than realistic. I find it quite interesting that wagar chose to place the development of the Commonwealth only after a massive nuclear holocaust had occurred. In my initial reading of the book, I assumed that wagar was implying that a socialist world state only had a chance in the aftermath of some massive crisis. But in his paper "Toward a Praxis of World Integration," which he presented at the American Sociological Association annual meetings in 1995, he denies that this was his intent. "It was never my intention in choosing this particular scenario," he writes, "to argue that only in the aftermath of a ruinous world war that destroys the core nations and drastically reduces the earth's population can humankind find a way to build a democratic and socialist world order" (1995:13). Perhaps not, but I think that for socialism to have a chance in the near future some sort of massive crisis will be needed as a precipitant. However, I myself would choose an ecological and economic catastrophe rather than a nuclear one. certainly the chances of nuclear war within the next

\section{[Page 4]}

\section{Joumal of World-Systems Research}

half-century are fairly high - at least 50-50 according to Christopher Chase-Dunn and Kenneth O'Reilly (1989). Yet I would argue that the chances of ecological devastation are considerably higher, almost a certainty perhaps, within the next 50 years.

In their recent book_Beyond the Limits_ (1992), Donella Meadows, Dennis Meadows, and Jorgen Randers ran a number of computer simulations that seem to show that a number of dramatic economic and ecological changes need to be made, and be made very soon, to permit an ecologically sustainable world. The authors ran 13 computer simulations involving various restrictions on industrial output or population growth, and only one of these yielded a sustainable world. For a sustainable world, Meadows, Meadows, and Randers showed that every single one of the following restrictions must be put into effect: pollution control, land yield enhancement, land erosion protection, a more resource-efficient technology, faster development of new technology, the limitation of every couple in the world to two children, 
and the reduction of the industrial output of the advanced capitalist countries to approximately the level of South korea. Anything short of this fails. Can it be done, or perhaps the better question is, will it be done? It is extremely hard to see how. The only way couples in Third world countries would limit themselves to two or fewer children is through the implementation of strict fertility policies by highly authoritarian and repressive governments, something along of the lines of what China has been doing since the 1970s. It can be done, but it is very difficult to imagine that it is likely to be done. As for the voluntary restriction of

\section{[Page 5]}

\section{Joumal of World-Systems Research}

industrial output by capitalists, this is almost

impossible to imagine. Robert Heilbroner (1980) argues that private individuals and groups will not voluntarily accept such restrictions but will have to be coerced, and this means the necessary rise of highly

authoritarian governments that could easily lead $t \circ$ the collapse of our basic democratic institutions. The restriction of industrial output on the part of capitalists would be economically suicidal in the short run, and every capitalist knows it. Capitalists all over the world will continue to bet that the doomsayers are wrong, and thus will mortgage the future. Inasmuch as the expanded accumulation of capital is the driving principle of the modern world, I can imagine capitalists abandoning that principle only under the most extreme circumstances. To my mind, it is likely to be abandoned only when a genuine crisis has ensued, and by that time it will probably be too late. As for governments compelling capitalists to reduce their industrial output markedly, I have serious doubts about that too given the enormous control that capitalists nomally have over the actions of states. Governments would probably be willing to exercise such coercion only when the crisis had arrived.

Wagar claims that a world state is essential to deal with the problems created by modern capitalism, and I couldn't agree more. But is wagar's particular conception of what this world state would have to be like a reasonable one? For wagar, this must be a socialist world commonwealth. As he says, "no effective and durable alte rnative to the capitalist world-system is imaginable except through a coordinated process of

[Page 6]

Journal of World-Systems Research 
world socialist revolution" (1995:15). But is this the only way? Wagar's Commonwealth seems to me to go considerably farther than what is really required. I would prefer a different kind of world state, one that had considerable coercive powers but that would nonetheless be less coercive and less overwhelming than Wagar's Commonwealth. I have in mind a world federati on that would exist in conjunction with a large number of nation-states, the latter being allowed to retain a certain amount of sovereignty, cultural distinctiveness, and self-determination. This federation would be a political structure above the level of the nation-state that would have the power to do two fundamental things: impose sharp limitations on the military operations of the individual nation-states, and engage in economic planning that would allow for a substantial amount of redistribution of wealth from the rich countries to the poor and that would help to produce an ecologically sustainable world. This world federation would not itself be socialist in outlook, but would attempt to combine the best features of capitalism and socialism while minimizing their most unattractive features. In my view, the more positive features of capitalism are its promotion of enormous scientific and technological development (despite the downside of this development); its promotion of enormous increases in econ omic productivity and the creation of wealth; its association with parliamentary democratic governments that, whatever their limitations, have been a vast improvement over the various despotisms of the past; and its promotion of enormous opportunities for the realization of human potential even if these opportunities have not been

\section{[Page 7]}

\section{Journal of World-Systems Research}

extended to the entire population. I see capitalism's main weaknesses as its creation of very high levels of economic inequality both within, and, especially, between nations; its generation of forms of work that have been associated with very high levels of boredom and alienation; its promotion of the intense commercialization of economic and social life and a consumerist mentality that has increasingly pushed other human values, especially those related to aesthetic and intellectual endeavors, into the background; its debilitating effects on the level of cultural life (as a result of its intense commercialization); and, as we know all too well, its dramatic impact on the natural environment.

What then are the strengths and weaknesses of socialism? Its main strengths lie in its much more humane concern for the welfare of all individuals in society and for a more egalitarian and ec onomically democratic form of social life. Its main weaknesses are 
well known. These are its tendency to centralize economic planning to an extent that produces a range of inefficiencies and other economic problems that lead to serious difficulties in the long run (cf. Kornai, 1992), and its tendency to concentrate political power in a huge bureaucracy that limits human freedom. Because of these difficulties, I am much less optimistic than world-system theorists and other Marxists concerning socialism's capacity to produce a mode of human existence truly superior to capitalism. I have gradually, and somewhat reluctantly, arrived at the conclusion that perhaps the best we can do, at least in the foreseeable future, is to extend to as much of the

\section{[Page 8]}

\section{Journal of World-Systems Research}

world as possible something like the Swedish model of social democracy. This means a capitalist system with a large number of built-in social and economic protections and a large amount of social and economic planning. A world federation that would seek to combine the best features of the plan and the market in the nation-states over which it exercises a substantial amount of control seems to me the most appropriate path to follow.

Wagar wants a world commonwealt $h$, it should be noted, only as part of a grand historicist (sensu Popper) future design. His Commonwealth is only a way-station to something better, a stage of historical development that must exist in order to produce the ideal future. And what is this ideal future? It is, as we have seen, a strongly decentralized world in which many small and highly autonomous political communties coexist. Putting aside the question as to whether such a denouement would be socially or politically desirable, is it realistic from a social-scientific point of view? Not from mine. As Robert Carneiro (1978) has convincingly shown, the overall trend of political evolution over the past 10,000 years has been from decentralization to centralization. From tens or hundreds of thousands of tiny bands and tribes of long ago we have been evolving in a direction marked by ever fewer and ever larger political units. The ultimate outcome of this political evolution, Carneiro argues, will be the formation of a single world state, wh ich he predicts is not all that far away. From this perspective, what sense does it make to assume that a gigantic Commonwealth will give way -- and quite

\section{[Page 9]}

\section{Journal of World-Systems Research}


harmoniously, it might be added -- to tens of thousands of little political islands each going its own way? Not much. Such an outcome overwhelmingly contradicts the evolutionary flow of all of world history and prehistory, and is extremely dubious.

But there is another problem, and that is that wagar assumes that the transition to thousands of tiny political communities will be a fundamentally peaceful and harmonious process resulting from democratic action. A gigantic world state with enormous coercive powers simply says, "Okay, guys, we see what you want; no problem, come and get it." And thus the smalls take over. But there is more to behold, for the smalls turn out to be very unusual individuals in that they have no interest in power or self-perpetuation, and as a result voluntarily put their political party out of existence only a few years after it achieved what it wanted. Is this the way politics works? Not for sociologists who appreciate Max weber, who characterized social life as essentially a continuous struggle for power. In fact when you think of it, there is remarkably little political struggle going on anywere in Wagar's futuristic scenario once capitalism has been defeated (actually, the defeat of capitalism hardly seemed to involve any political struggle either). One has to wonder, exactly what kinds of human organisms are these that populate Wagar's world? Despite its insights, Marxism has always suffered from a number of fatal flaws. With respect to the concerns taken up by Wagar, the most serious flaw is the unbelievably naive conception of politics held by Marx and many Marxists since Marx's day. The state is

\section{[Page 10]}

\section{Journal of World-Systems Research}

largely there to serve the interests of a ruling class, and when such a class is no longer on the historical stage the state's ruling functions disappear. The events of 1917 in Russia, of 1949 in China, and of 1959 in Cuba have made mincemeat of this idea. But wagar still seems to hold onto it, or something like it, and it creates major problems for his futuristic projections.

One of the things that impressed me most about the paper wagar presented at the 1995 ASA meetings was his exposing of contemporary multiculturalism for the folly that it most surely is. In this vision, somehow "radical feminism, fundamentalist Islam, populist libertarianism, militant Hinduism, Marxian socialism, born-again Christianity, megacorporate capitalism, Bosnian nationalism, serbian nationalism, and all the other colliding forces at work in our whirling world 
somehow lie down together like lions and lambs in the New Jerusalem and agree to eat grass, or better yet, develop the capacity to feed themselves by photosynthesis" (Wagar, 1995:1-2). As wagar comments, this is a wonderfully "nice" solution to the huge problems of the contemporary world; the only problem with it is that it is hopelessly wrong. A number of years ago the sociologist orlando Patterson wrote a book entitled Ethnic Chauvinism: The Reactionary Impulse (1977) in which he argued that ethnic pluralism was a prescription for disaster and the only hope for humankind was some sort of large-scale blending of cultures. wagar would seem to agree, and this kind of thinking is no doubt what is behind his notion that a single world state is necessary to prevent extremely divisive ideologies like Islamic fundamentalism from acquiring political legitimacy. I find myself in agreement with both Patterson and wagar on this point,

\section{[Page 11]}

\section{Journal of World-Systems Reseurch}

but there is a serious inconsistency in Wagar's

thinking. If wagar anticipates the horrendously divisive results that multiculturalism is likely to produce, then why on earth does he favor a highly decentralized world future in which people live in small political communities notable for their sharp cultural, economic, and political differences? Won't this lead us right back toward the kind of divisiveness he wants to avoid, and, moreover, won't the way be paved for a resumption of capitalism and of the evolutionary process whereby many small political units event ually become one big one? On the other hand, perhaps this will be avoided, because Wagar's 41,525 political communities of the twenty-third century don't really interact with each other much and just sort of live happily ever after!

I admire Wagar's book and think that it gives us some enormous food for thought about some of the things the future is likely to bring. It is an extremely important contribution, and I don't want my criticisms of it to be seen as some sort of casual dismissal. I certainly don't feel that way about it. In closing I would simply like to raise a question: Is it rational for people in the world of the late second millennium $A D$ to form the equivalent of a world Party and struggle for a better world. Yes, I think it is, altho ugh I have little idea as to just how that sort of thing should be done. At this point in history, we are in serious trouble and unless some dramatic changes are made one or another type of catastrophe awaits. Yes, let's form a world Party, but let's also be realistic about its possibilities. If it can, theory should lead to praxis. Yet we all know how difficult good theory can be, and 
[Page 12]

Journal of World-Systems Research

let us not forget that good praxis is undoubtedly even

harder.

REFERENCES

Carneiro, Robert. 1978. "Political Expansion as an

Expression of the Principle of Competitive Exclusion."

In Ronald Cohen and Elman R. Service (eds.), Origins

of the State. Philadelphia: Institute for the study of

Human Issues.

Chase-Dunn, Christopher, and Kenneth O'Reilly. 1989.

"Core wars of the Future." In Robert K. Schaeffer (ed.),

War in the World-System_. Westport, CT: Greenwood

Press.

Heilbroner, Robert L. 1980. An Inquiry into the Human

Prospect_. New York: Norton.

Kornai, Janos. 1992. The Socialist System: The

Political Economy of Communism. Princeton, NJ: Princeton

University Press.

Meadows, Donella H., Dennis L. Meadows, and Jorgen

Randers. 1992. Beyond the Limits: Confronting Global

Collapse, Envisioning a Sustainable Future_. Post Mills, VT:

Chelsea Green.

Patterson, Orlando. 1977. Ethnic Chauvinism: The

Reactionary Impulse_. New York: Stein and Day.

\section{[Page 13]}

Journal of World-Systems Research

wagar, w. Warren. 1992. A Short History of the Future_.

2nd edition. Chicago: University of Chicago Press.

$$
\text { 1995. "Toward a Praxis of World }
$$

Integration." Paper presented at the annual meetings of the American Sociological Association, Washington, D.C.,

August 19-23.

\section{[Page 14]}

Journal of World-Systems Research 